\title{
Critical Insurance Studies: Some geographic directions
}

\begin{abstract}
Critical insurance studies recognises insurance as not purely actuarial and calculative. From this recognition, this theoretically informed research pays attention to the re-production of power in insurantial discourse and practice, and possibilities for equitable change. To extend geographical contributions in this regard, I review critical insurance research and describe three intersecting foci - governmentality, materiality and spatiality. I also contribute new insights in considering insurance as co-constituting fluid and fire space - as flowing and adapting within everyday complexities, and as fiery and constituted through multiple flickering realities. These contestable multiplicities and mobilities may contribute to more equitable configurations beyond the hegemonic.
\end{abstract}

\section{Introduction}

Insurance is public 'common sense' in many liberal democracies and is broadly accepted as an essential part of everyday life. Yet, the hegemony of neoliberal notions of individualisation and self-responsibility produces insurantial norms that define 'good' and 'bad' citizens based on having or not having insurance (Booth and Harwood, 2016; Langley, 2006). As such insurance is implicated in the re-production of patterns of inequality and inequity. The insurance sector is also one of the most powerful players in global finances and is positioning itself as central in climate action, at least in terms of the insurance of property and assets (Lobo-Guerrero, 2010). In response to this nexus of power, crisis and injustice, there is a growing body of insurance research within human geography, and the social sciences more generally ${ }^{\mathrm{i}}$.

Prior to this recent emergence of what can be termed 'critical insurance studies', the bulk of insurance research was made up of positivist approaches applied in economics and finance. Premised on the historic framing of insurance in actuarialism and calculative practices, these assume that insurance is a benign consumer product, financial mechanism or risk management tool (e.g. Kiohos and Paspati, 2021; Pitthan and De Witte, 2021). Conceived in this way, insurance is attractive to neoliberal-inclined governments particularly in Western countries. It appears to be an ideal tool in the context of the withdrawal of the state and the individualisation of risk and responsibility. It looks like a straightforward and achievable alternative to socialised support and welfare, with market dynamics, in theory, enabling 
greater insurance availability, increased insurance uptake and more informed insurance decision-making on behalf of those at risk.

As everyday life has become tightly bound within hegemonic financial and insurantial logics, these logics have become normalised and normative (Lobo-Guerrero, 2013). They can take on the appearance of a natural given (Mouffe, 2005). It appears commonsensical, for example, that: converting everything into capital is a fait accompli (Lehtonen and Van Hoyweghen, 2014); that expanding what constitutes 'everything' through innovations like insurance-linked securitisation is a benign and unproblematic pathway to profit; that, of course, one should take responsibility for one's own risks; that insurance is the ideal and obvious risk management tool; and, that as a good citizen, one would have insurance - for health, life, property and so on. Yet, more complexly, the enactment of such 'common sense' is rapidly and radically reconfiguring places and spaces, and with it, lives. This is occurring without accountability and transparency, and appears particularly problematic regarding how these changes are contributing to growing inequality and inequity (Booth, 2020; Grove, 2012; Johnson, 2015).

Like other forms of critical enquiry, critical insurance studies complicates and disrupts neoliberal expectations and narratives. Although a diverse field, one central tenet unites what could otherwise appear to be a disparate collection of work. There is collective recognition that insurance is not and has never been purely actuarial and calculative (e.g. McFall, 2015). As Ericson and Doyle (2004: 138) observe, there have always been gaps and absences in risk calculation and these are addressed through 'non-scientific forms of knowledge that are intuitive, emotional, aesthetic, moral, and speculative'. For example, O’Malley and Robert (2013) describe how fire insurance for property in Australia was not premised on actuarial calculations until 100 years after life insurance had adopted this statistical-archival method. Instead, prior to the 1920s, door-to-door salesmen conducted assessments of 'cumulative dangerousness' which included an assessment of both the structural and moral risks posed by each household - the risk of fire borne through building structure and the risk borne through the moral fabric of the householders.

It is from this tenet that critical insurance studies challenges the 'common sense' of marketbased economics, reveals the contradictions, tensions and schisms apparent within associated logics, and posits other more equitable possibilities. 
In this paper, my aim is to set some geographical directions for growing this body of work, beginning with a review of critical insurance literature. I focus on three loose and at times overlapping groupings of research pertaining to different relational configurations governmentality, materiality and spatiality. These groupings are intended to be interpretive and are not designed as a comprehensive categorisation or genealogy of critical insurance studies. As all are premised on insurance as in some sense relationally constituted, I am interested in how each relational configuration complements and extends the other.

To extend thoughts and research beyond the existing literature, I conclude the paper in dialogue with Law and colleagues' critique of relationality as apparent in actor-network theory (Law, 2002; Law and Mol, 2001; Law and Singleton, 2005). I make a case for mobilising alternative spatialities in critical insurance studies, specifically the notions of fluid and fire space. I argue that explicitly adopting these types of spatiality can assist in further illustrating and addressing the power and inequity of insurance, and in geographies of money and finance more generally. This can contribute to re-imaging and implementing more sociospatially equitable financial futures.

It is important to note that the purpose of this paper is not to set hard boundaries around critical insurance studies. This review is not a systematic review of critical enquiry that extends across multiple disciplines. It instead focuses on research that appears most pertinent to human geography, specifically geographical and sociological research, and aims to represent diversity in critical insurance studies and thus extend the possibilities for emergent human geographical research. There is tremendous scope for more critical research on insurance including tighter engagement across, for example, economics, finance, health, sociology and geography, and diversifying foci on private health insurance, national pension insurance schemes, and climate-related insurance.

\section{Insurance research}

Critical insurance studies takes its impetus from critical enquiry that adopts a leftist posture including a concern with power and inequity. While lacking a distinct theoretical identity, critical studies can be recognised for its rejection of positivism, the pursuit of freedom from injustice and a focus on everyday change rather than grand revolution (cf. Agger, 1998; Fay, 1987). The characteristics of critical human geography, for example, include a commitment to social theory, social change and emancipatory politics, contesting the power emanating 
through representation such as discourse, and critical approaches to spatial orderings and representations that produce inequality and inequity ${ }^{\mathrm{ii}}$ (Blomley, 2009).

Critical insurance studies is located within critical finance studies. The characteristics of this diverse field are contested and contestable. However, as Borch (2020) describes, in addressing power and injustice, critical finance studies foregrounds theoretically informed empirical research, and approaches economics and finance as social as well as financial phenomena. In focusing on large and complex financial processes, systems and institutions or on everyday household financial discourses and practices, it is the historically contingent discourses and practices of people - stockbrokers, accountants, 'mum and dad' investors etc. - that co-constitute financial life, rather than a rarefied notion of monetary finance.

While critical finance studies varies in its theoretical underpinnings and modes of critique, it remains committed to the characteristics of critical enquiry outlined above. As Borch (2020) specifies with reference to the Foucauldian notion of governmentalisation, critical finance studies encompasses a broad commitment to questioning how people are governed and the discourses and practices of control exercised by governments and other powerful financial institutions and systems. Critical enquiry thus brings to the fore insights and perspectives on "“the art of not being governed quite so much" or, more precisely, the art of not being governed thus' (Foucault, cited in Borch, 2020: 12).

In doing this, critical insurance studies draws implicitly and explicitly upon Foucauldian thought, while embracing two other themes resonating within critical finance studies more generally. The first is the adoption of multiple conceptual lenses such as subjectivity, households and society (Borch, 2020). The second is recognising and addressing blind spots in how each of these (and other concepts) are constituted. There is an expanded recognition of the affective and more-than-human dimensions that may configure financial and particularly, insurantial discourses and practices. This includes an emphasis on how global finances and associated insurance logics, and everyday life interlink and co-constitute each other, for example, research that mobilises households as a scale, as a node in an extensive network of relations, or as a place imbued with the emotionalities and materialities of lived experience (Harker and Montgomerie, 2021).

To better understand the significance and scope of critical insurance studies, as previously introduced, in this section I divide my review of scholarship into three, a division premised on different configurations of relationality. The first grouping is focused on literature 
pertaining to governmentality and relational configurations of insurance, institutions, morality, power and subjectivity. The second is research concerned with materiality and how insurance is constituted through everyday human-non-human relationships imbued with affect, emotion and, again, morality. The third considers research that overtly brings spatiality into considerations of the places and spaces of insurance discourse and practice.

\section{Governmentality}

As in critical finance studies, Foucauldian ideas of governmentality are mobilised in critical insurance studies to illustrate and challenge structures of governance within, and 'being governed' through insurance discourse and practice. Ewald (1991), for example, identifies three denotations of insurance. One is the diversity of institutions that unite to make what is broadly recognised as 'insurance'. Two is insurance as a technology, in which 'insurance is an art of combining various elements of economic and social reality according to a set of specific rules' (Ewald, 1991: 197). This frequently involves both government and insurance institutions (Clark, 2003; Collier, 2014). Depending on where, when and what type of insurance, these may be government-owned insurance schemes that enact insurantial logics (see for example McAneney et al., 2016), public-private partnerships that constitute particular insurance technologies (see for example Christophers, 2019; Langley, 2006; Nance, 2015) or government regulation of insurers and insurance operations within a nation state (see for example ACCC, 2019). Governments may also promote private insurance as part of individualised risk and responsibilisation agendas, mobilising insurance rationale and logics in the process (Booth and Kendal, 2020).

Three is premised on the co-constitution of the institutions and the technology, and when insurance takes on different forms or shapes:

Insurance technology and actuarial science did not fall from the mathematical skies to incarnate themselves in institutions. They were built up gradually out of multiple practices which they reflected and rationalised, practices of which they were more effects than causes, and it would be wrong to imagine that they have now assumed a definite shape. Existing in economic, moral and political conjunctures which continually alter, the practice of insurance is always reshaping its techniques (Ewald, 1991: 198). 
While remaining concerned with calculability, collectivity and capital, insurance embodies a shifting set of rationales or logics that are constantly being remade. Thus, insurance is a political technology in that it both articulates power and enables individuals to agree to being articulated through this power. For example, in embracing the insurantial logic emergent in the 1800s, workers were able to pay a minimal contribution and safeguard themselves against labour-based misfortune. This was a re-configuration of the politics of labour as much as a roll out of a new technology. It was also a reconfiguration of the politics of self; of 'the art of being governed thus' (Foucault, cited in Borch, 2020: 12).

Lobo-Guerrero (2013) also observes, drawing upon Foucauldian thought, the unequal distribution of power between insurers and insurees and how this embodies a problematic form of governance premised on social and moral coercion. Relations are 'coaxed', reproducing norms of insurance practice (Booth and Harwood, 2016; Johnson, 2013a; Lo, 2013). A key mechanism here is the principle of utmost good faith, or uberruma fides. Through this legal principle, insurance appears to 'trade in trust' by supposing, ...that both parties to the insurance transaction provide relevant and sufficient information that will help them make an informed decision on the insurability of the event to be covered, in the case of the underwriter, and the usefulness, value, and relevance of the insurance product on offer in the case of the buyer (Lobo- Guerrero, 2013: 26).

Yet, this reproduction of trust is inevitably enmeshed within systems of control and power (Knight et al., 2001), and it is consumers whose decisions and actions on information disclosure that are prescribed and coerced. This is both through the legalities of insurance and through a complex subjectification manifest through the normalisation of insurance. As discussed in more detail below, consumers do (part of) the work in upholding the value of being insured, while manifesting diminished power and a sense of dependency. Tranter and Booth (2019), in fact, argue that fatalistic dependency is a key contributor to insurance decision-making rather than trust per se. Consumers feel that 'they have little choice but to be insured, even if they do not necessarily trust insurance companies' (Tranter and Booth, 2019: 205). Such dependency is powerfully co-constituted through the normalisation and normatisation of insurance. 
It is interesting to note that these kinds of insights sit counter to evolving notions of moral hazard, indicating a more complex terrain of power. In signposting a concern that insurance possessing insurance - can lessen an individual's motivation for risk aversion and encourage bad behaviour, moral hazard places the insurer in the less empowered position (Baker, 1996; Meyers and Van Hoyweghen, 2018). Instead, in being at the whim of irresponsible and perhaps, dishonest action on behalf of customers, insurers are at risk themselves.

\section{Materiality}

While rarely explicitly discussed in governmentality-oriented research, notions of control, power, trust and dependency imply a range of affective and emotional responses on behalf of those interacting with insurance. Trust and mistrust, for example, may be calculated, rational responses to experiences and perceptions of control and power, but these also embody emotions (Tranter and Booth, 2019). As McFall (2011) observes:

Ewald's (1991) definition of insurance as a technology that compensates for the effects of chance through the mechanism of mutuality organized according to the laws of large numbers may capture the essentials but it also skates over the strange and varied ways insurance has been made to work. Insurance may be a technical method of risk spreading, it may be more or less efficient depending on the technical and methodological arrangements employed, but it is more than this. As far as its publics, its consumers are concerned; insurance is a promise... (McFall, 2011: 665).

As a 'promise', insurance is potentially unique when compared with other mass-marketed consumables, as 'insurance derives from ties of love, fear and security in peculiar combination with the relations of chance, risk and logic' (McFall, 2011: 666).

There is a body of critical insurance studies preoccupied with these kinds of complex ties and how they materialise in everyday life. While there appears to be little research that overtly identifies materiality as a key theoretical framing (an exception includes Lehtonen, 2014), the openness implied by this concept appears pertinent. Specifically, it provides an umbrella for research that foregrounds the entwining of affect, emotions and human-non-human agencies and how these constitute everyday insurance discourse and practice. Anderson and Wylie (2009: 318), for example, identify three broad approaches to materiality in geographical research. One focuses on encounters with and practices involving environments and objects, a 
second is concerned with the 'varied intertwined materialities of nature, science, and technology', and a third in which bodies, sensation, emotion and affect co-constitute materiality. Thus, the 'material' exceeds matter in its concrete and earthly form and instead incorporates all aspects - earth, air, fire and water - and recognises these as relationally dynamic or lively (Anderson and Wylie, 2009; Bennett, 2009).

The affective and emotional qualities of insurance were made evident in early work considering the social constitution of insurance, particularly work by Zelizer (2017). In documenting the shifting moralities surrounding the rapid uptake of life insurance in the United States in the nineteenth century, she identified how initial resistance to this product was overcome in repeated conversations between door-to-door salesmen and householders. Religiously informed norms had maintained human life, and thus, death as sacred and beyond all monetary and material measures. While this valuation remained, by and large, intact, insurance companies and their salesmen worked to effectively lift money into the realm of the sacred through transforming the ritualisation of death: 'Life insurance took on symbolic values quite distinct from its utilitarian function, emerging as a new form of ritual with which to face death and a processing of the dead by those kin left behind' (Zelizer, 2017: 151). The door-to-door selling of life insurance, invoked - deliberately invoked - insurance as a promise as well as a financial product; promising feelings of 'safety, belonging and respectability' (McFall, 2011: 680) as well as providing a financial safety net in the event of misfortune.

Stirring the emotions has long been part of the insurance sectors marketing repertoire. Such complexity continues to reproduce the 'bricolage qualities' of insurance (French and Kneale, 2015: 17) - a bricolage of safety net, moral signifier, affective promise, and calculable financial gain. Booth and Harwood (2016) identify what appear to be resonances of historic norms in contemporary households at risk of bushfire, where people identify 'good' insured type people as distinct from the non-insured. As well as garnering feelings of love and responsibility, house and contents insurance also produces fear and anxiety as a distrust of insurers and a general sense of uncertainty pervades imaginings of what would happen if homes were destroyed and claims needed to be made (Booth, 2021; Booth and Harwood, 2016).

Anxiety and uncertainty also arise in relation to the possibility of a loss of insurability (LoboGuerrero, 2014) and because of unforeseen contradictions resulting from new insurance initiatives. In the United Kingdom, for example, lower premiums were offered to those with 
lower life expectancies resulting from 'lives lived carelessly' (French and Kneale, 2012), acting in contradiction to government health messaging. Those who were healthy - perhaps living careful, responsibilised lives - were effectively punished through higher premium prices. Thus, those considered to be self-responsibilised and good risk bearers (Langley, 2006) - a contemporary manifestation of the normative insurantial subjectivities described by McFall (2011) and Zelizer (2017) - can find that their effects go unrewarded through the bricolaged co-constitution of profit, morality and promise. In this regard, the normalisation and 'domestication' (Lehtonen, 2017) of life insurance pursued by insurers can have unpleasant, if not violent consequences for those excluded from insurance or included but not rewarded or valued in the expected or promised way. As Booth (2021) observes, people can feel validated when an insurance claim is successful or feel that their self-worth is brought into question when insurance does not come through as expected. The latter can contribute to an intense sense of betrayal and distrust of insurance companies.

Other new insurance technologies (e.g. Meyers and Van Hoyweghen, 2020; Tanninen, 2020) are also creating effects - some expected and others unforeseen. McFall (2019) describes how insurtech - high tech changes including big data analytics and artificial intelligence applications - could disrupt insurance to such an extent that it is, in short, no longer insurance:

Conceptually, insurance organizes solidarity across groups by balancing risk distribution and assessment. Personalizing solidarity to make risk an assessed and priced property of individuals would tip the balance so far towards assessment that it is not clear that any eventual product would qualify as insurance (McFall, 2019: 70).

However, the historic lineage of risk classification and pricing suggests that this is unlikely, as these have long been co-constituted through a diversity of non-scientific logics - affective, emotional, material (McFall and Moor, 2018). Insurtech, rather than being a definitive transformation, will likely co-produce insurance that resonates with both historic and novel social complexities as it is mobilised by insurers through, for example, 'sentimental appeal' in personalised insurance product branding (Jeanningros and McFall, 2020) and enters the homes and lives of policyholders.

\section{Spatiality}


In critical insurance studies, governmentality perspectives - particularly Ewald's (1991) work - draw attention to the relational, temporal dynamism of insurance, and work considering everyday materialities foreground a range of qualities and agencies which co-constitute insurance. There is another body of (ofttimes overlapping) work, that mobilises place and space explicitly in its formulation, and contributes to addressing a lacuna of geographical insights into the spatial variegations of economics and finance more generally (Booth, 2021; Hall, 2010; Pike and Pollard, 2010). As French et al. (2011) argue, when reflecting on the strengthening ties between global finances systems and all aspects of life through the process of financialisation:

that for the concept of financialization to serve as an effective rallying point for researchers working on the social consequences of money and finance... and as a means by which to intervene in contemporary policy debates, it needs to address a glaring lacuna at the heart of the financialization project; that is, its relative uncritical approach to the role of space and place within monetary and financial processes (French et al., 2011: 805).

In critical insurance studies, insurance is broadly recognised as spatially and temporally variegated (Booth and Harwood, 2016; Booth and Kendal, 2020), and as a spatially and temporally diverse agent in the co-constitution of everyday life (Ossandón, 2014). There is research grounded in different types of places: homes and households (e.g. Booth and Harwood, 2016; Lehtonen, 2017); disaster-prone areas (e.g. Booth, 2021; Elliot, 2019; Taylor, 2020); nation states (e.g. Christophers, 2019; Elliot, 2017; Ossandón, 2014; Booth and Tranter, 2018); and, regions (e.g. Grove, 2012; Johnson 2013b; Lobo-Guerrero, 2010). There is also research that considers the shifting scales of insurance markets (e.g. Christophers et al., 2020; Johnson, 2015), insurance as co-constituted through network space (e.g. Meyers and Van Hoyweghen, 2020; Ossandón, 2014; Taylor, 2020; Van Hoyweghen, 2010), spatial imaginings that constitute insurantial discourse (e.g. Lobo-Guerrero, 2014), and insurance as co-constituting financialised spaces (e.g. French and Kneale, 2009).

In financial geography, households tend to be mobilised in three ways - as a scale, as a node in an extensive network of relations, or as a place imbued with the emotionalities and materialities of lived experience (Harker and Montgomerie, 2021). These approaches are mirrored in critical insurance studies. For example, as reviewed above, householder experiences and perceptions of house and contents insurance reveal a complexity of affect 
and emotions that co-constitute insurance and the home as a place (Booth, 2021; Booth and Harwood, 2016). Lehtonen (2017) also explores how health insurance becomes 'domesticated' within the everyday practices of Finnish families. This includes how the scale of the household is interlinked with the larger scale of global finance, and how this informs household decision-making and understandings.

Along similar lines, disaster-prone areas, nation states and regions may be approached as landscapes imbued with the materialities of lived experience, nodes of expansive networks, as locations identifiable in terms of longitude and latitude coordinates or as places defined by sovereign borders. Booth (2021), for example, identifies insuring as a practice embedded within disaster-prone landscapes. Focusing specifically on house and contents insurance, she describes how the act of insuring is manifest within places burnt by wildfire. Charred stumps, surviving buildings and handed-down stories act as reminders that inform how people understand insurance, its capacities and limitations, and thus, if and how they practice insuring.

More quantitative studies consider socio-demographic patterns in insurance uptake and perceptions at a national scale and how these map onto particular urban areas. Drawing on Australian national survey data, Booth and Tranter (2018) signpost how such patterns indicate the possibility of political dissent as mistrust in insurers converges with the attempted withdrawal of governments from disaster management and planning. Similar national survey data also presents a picture of the relationship between trust and insurance in Australia, leading to a socio-spatial conception of trust that is socially and spatially variegated, and relationally dynamic (Tranter and Booth, 2019). In creating and mapping an underinsurance index from this survey data, Booth and Kendal (2020) illustrate spatial patterns in insurance uptake that challenge the idea that socio-economic status is a key driver of underinsurance. Instead, it is housing tenure - renting - that largely informs the spatial distribution of underinsurance. As disasters intensify and become more frequent through climatic change, this may contribute to producing new and novel types of social and urban divide (Booth and Kendal, 2020; Johnson, 2015).

There is also a body of research that looks more generally at insurance through the loose geographical frames of the developing world or the Global South. Johnson (2013b) considers the roll out of index insurance (or more accurately, derivatives) by the United Nations and development NGOs in partnership with insurers, and how this acts to expand insurability in relation to climate, disaster and agricultural uncertainty by creating indexes from factors such 
as rainfall, wind speed, soil moisture and crop yield (Johnson, 2013b). This type of insurance may undermine informal, collective forms of adaptation, insurance and survival by mandating seed and crop types, agro-chemical usage, and tying subsistence farms to large scale agricultural production with negative environmental and social consequences (Müller et al., 2017). It can also have potential benefits as it undercuts the need for ownership on which much insurance is predicated (Johnson, 2013b).

Another type of index insurance, catastrophe bonds, form the basis of inter-nation insurance schemes and act to extend the scope of insurability (Johnson, 2013a). For example, hurricanes were previously deemed uninsurable in the Caribbean, and the instigation of the Caribbean Catastrophic Risk Insurance Facility (CCRIF) across 16 nations provided insurance in relation to specified events. Yet, how the payouts from this scheme are used and distributed by individual nation states has meant that the CCRIF is less about protecting vulnerable populations and more about national security; of mitigating state failure and social disorder (Grove, 2012; Lobo-Guerrera, 2011).

With reference to climate or adaptive migrants in the developing world, Baldwin (2017) also observes polarisation pertaining to who is and who is not insurable. Those who can participate in international labour markets and insure their income and travel, exhibit acceptable adaptive capacities in accessing global financial and information networks. Adaptive migrants are thus conceived as financialised migrants. Those who are nonfinancialised and uninsured or uninsurable - who move, for example, to informal settlements and potentially precarious situations - are deemed maladaptive (Baldwin, 2017). This apparent lack of adaptation is defined on market terms. It is about maladaptation to the emerging and evolving regime of global financial risk, and is not maladaptation to a changing climate per se.

Each of the accounts of place and space reviewed here share one definable feature - all can be pinpointed on a map. All share a Cartesian or Euclidean spatiality even though some also exhibit other forms of spatiality such as network space (discussed further below). LoboGuerrero (2014), on the other hand, evokes a spatial imaginary that exceeds ideas of Cartesian or Euclidean space. This spatiality correlates with imaginings of who is and who is not insurable - on the 'inside' are those whose lives are insurable, and on the 'outside' are those whose lives are not. While the inside and outside exist as separate realms, they are also interdependent. Insurability in the form of manageable risk and security is interdependent with non-insurability in the form of unmanageable risk and insecurity. For insurability to 
exist, non-insurability must also exist as each of these spaces is co-constituting; one cannot exist without the other as it is not possible to calculate and rationalise something if it is all or nothing.

\section{Some geographic directions}

In reviewing themes of governmentality, materiality and spatiality, there appears ample room to extend insurance research in human geography, particularly with reference to one of the most common spatial articulations - network space. Network space is informed by actornetwork theory and as noted above, is also evident in critical insurance studies (e.g. Elliot, 2017; Ossandón, 2014; Taylor, 2020; Van Hoyweghen, 2010). Actor-network theory conceives a world constituted through the dynamic networks of relationships between human and non-human actants (e.g. Latour, 1990). Things, entities and processes are described as networks in that each exists through a complexity of relations. These things, entities and processes also constitute networks as actants. Such networks may be locatable in terms of undifferentiated Cartesian or Euclidean space, yet the nature of networks means that they can also co-constitute very different kinds of space. As Murdoch (1998: 357) describes, network space is differentiated in that it 'cannot readily co-exist with a notion of space as fixed and absolute in its co-ordinates'. For example, a network may include relations that appear distant on a map but within the network these relations may lie in close proximity.

As introduced above, a double spatiality exists in some accounts of insurance - an interdependence or juxtaposition of Cartesian or Euclidean and network space. This is not necessarily problematic (Law and Mol, 2001), however, it does present alternative pathways for thinking about insurance spatially. Law and colleagues (Law, 2002; Law and Mol, 2001; Law and Singleton, 2005), in identifying a double spatiality in some mobile objects (for example, a sailing ship), observe that an object is mobile as it traverses the earth's surface as defined by the coordinates of longitude and latitude. However, if that object is also constituted through a stable, immutable network of relations that maintain its form as that object, it is also immobile. As its location in Cartesian and Euclidean space changes, as a network it does not change. Thus, in network space and counter to Latour's (1990) associated notion of 'immutable mobiles', an object can be both immutable and immobile, rather than immutable and mobile (Law and Mol, 2002).

An example of how this is enacted in critical insurance studies comes from Taylor (2020) who takes a network approach in understanding the 'expansive assemblage of properties, 
institutions and regulations, capital flows, and embodied expertise which work in concert to secure specific geographical circuits of property-led accumulation' in Florida in the United States (Taylor, 2020: 1143). As he describes, insurance-linked securitisation takes capital from investors in places like Europe and the United States and transforms this into reinsurance - insurance for insurers. The basis for this is the securitisation of annual household insurance policy payments, and an outcome is the protection of real estate markets and the maintenance of property accumulation and investment in hurricane-prone Florida. Despite increasing climate risks, this form of securitisation ensures that insurance is available to households in disaster areas, provides local governments with a stable and liquid revenue base and, the primary driver, provides a relatively stable and steady income stream for (re)insurers and investors (Taylor, 2020).

In Taylor's (2020) analysis, insurance retains a stable form as a network (network space), and this stable network is an actant that connects different places such as Europe and the United States including Florida (Cartesian or Euclidean space). Yet, there is also more at play in Taylor's (2020) analysis, as there is also the complex and dynamic network of global finance within which insurance is both a constituting agent and through which insurance is constituted. This dynamic constitution of insurance does not appear accounted for through either Cartesian or network space.

\section{Fluid and fiery insurance}

For Law and colleagues, recognising the co-joining of distinct spatialities draws attention to other, more complex possibilities in the co-constitution space. This includes space coconstituted through objects that do not reliably hold their form i.e. objects that are slowly and gradually mutable though are still recognisable as themselves - fluid space (Law, 2002; Law and Mol, 2001; Law and Singleton, 2005). For example, Law and Mol (2001) describe how water pumps in remote Zimbabwe are repaired and modified to meet local needs. Thus, the pump, '...looks different from one village to the next, and it works differently from one setup to the next... It is a mutable mobile... yet it makes sense to say that it is "the same pump". (Law and Mol, 2001: 613). The variance of this type of object does not represent a 'failed network', it is instead a defining feature. So much so that the object holds recognisable form because change occurs; continuance of the object is ensured through its fluid adaptation.

Resonances of a similar fluidity appear evident in some aspects of critical insurance studies. In Northern Kenya, for example, the success of selling the same livestock insurance product 
varies across villages, influenced by localised weather predictions divined from goats' entrails (Johnson, 2013b). The agency of the diviners and the goat guts co-constitute the fluidity of insurance within these landscapes, as insurance takes on different forms as it travels and adapts to local knowledges and traditions. These adaptations are gradual and slow enough for this type of insurance to maintain its form, and also appear instrumental in ensuring its continuance as these insurances remain recognisable as livestock insurance. Likewise, it is possible to re-understand other types of insurance, such as that described by Taylor (2020), in more fluid terms - as constituted through the evolving malleability of global finance. Insurance, rather than holding stable form, adapts and is remade through the process of securitisation, and this fluidity ensures that insurance remains possible - remains a reality - in places like hurricane-prone Florida.

Recognising the co-joining of distinct spatialities also draws attention to space constituted through another manifestation of movement - where an object's continuity is dependent on discontinuity:

As with fluid constancy, movement rather than stasis is crucial.

Without movement there is no consistency. The difference is that, whereas in fluidity constancy depends on gradual change, in a topology of fire constancy is produced in abrupt and discontinuous movements (Law and Mol, 2001: 615).

This fire space is constituted through the interdependence of 'flickering' presences and absences in an object's relational configuration (Jong and M'charek, 2018; Law, 2002; Law and Mol, 2001; Law and Singleton, 2005). The same object is variously constituted in different locations with each version of the same object existing as a reality potentially discontinuous from other versions. In demonstrating multiple realities that are at times mutually exclusive, continuance of this kind of object is dependent upon abrupt and disruptive internal movement.

Booth and Harwood (2016), for example, observe how house and contents insurance in bushfire-prone Australia is co-constituted through 'insurantial moments.' From one moment to the next the same insurance product - the same insurance policy - takes on different forms - as risk management tool, as signifier of love and responsibility, or as demonstrator of adhering to social norms. This insurance demonstrates a mutable internal spatiality, but not of a fluid kind. Instead, different versions of the same insurance 'take the form of jumps and 
discontinuities... energetic, entities or processes that juxtapose, distinguish, make and transform absences and presences' (Law and Singleton, 2005: 343-4). Yet, it is still identifiable and recognisable as house and contents insurance as it is the constant discontinuities that constitute the continuance of its recognisable form.

The juxtaposition evident in what index insurance is for subsistence farmers and what it is for development organisations provides another example of how insurance can be co-constituted through fire space. For farmers, their insurance reality is (or realities are) co-constituted with traditional knowledge such as divination and local weather events (Johnson, 2013b). For the development agencies who promote it, insurance is a means of adaptation and sustainability. The lack of control by the purveyors of index insurance, in reconciling these two realities, can render it 'uncontrollable and generative of othernesses' (Law and Singleton, 2005: 347) as both realities embody very different patterns of 'flickering' presence and absence. This may threaten discontinuity, but disruption and disjuncture also appear necessary to the continuity of index insurance. In this context, index insurance is being mobilised as a means of integrating subsistence farmers in global agricultural systems (Johnson, 2013b). This insurance is ultimately embedded in and enabled by a disruption of the traditional knowledges and farming practices that currently constitute the farmers' reality.

While different types of insurance can be recognised as immutable in network space, for example, house and contents insurance, life insurance, index insurance (even if these evolve through time) and these can be mapped and tracked as they are distributed to and sold in different places (through Cartesian or Euclidean space), these different types of insurance are also internally dynamic. Understood as co-constituting fluid or fiery space, they are mutable in their mobility. This extends Ewald's (1991) conceptualisation of insurance as constantly changing and being reworked over time into new types of insurance, as it foregrounds the same type of insurance as internally fluid or fiery. The same insurance is its own different insurances (Law, 2002).

\section{Multiplicity and mobility}

Foregrounding fluid and fiery spatialities does not do away with the importance and value of research that enacts the double spatialities described by Law and colleagues, or even research in critical insurance studies that does not explicitly engage with place and space. In revealing more insurance realities rather than specifying a singular or bounded suite of realities, this multiplicity signposts research that more closely considers the ontologies of insurance and 
draws fresh attention to the question 'what is insurance?' This in turn points towards modes of knowing that are open and sensitive to movement and mutability within insurance, and what this means for insurance praxis - the enactment or realisation of these theoretical insights through practice and politics.

The idea of mutability or mobility deserves further exploration particularly in regard to the political impetus of critical studies. The uneven power distribution between insurers and customers identified by Lobo-Guerrero (2013) speaks to fluid or fiery adaptation where insurers can and do act as harbingers of flow and 'flickering'. As Knight et al. (2001: 318) observe in relation to production of trust in the selling of goods and services, this production is enmeshed within systems of control and power, and the 'task of the various corporate actors is to come up with novel legal, social or technical mechanisms of control and trust production'. Insurers exert considerable agency in co-constituting their products through social norms (McFall, 2011; O’Malley and Roberts, 2013; Zelizer, 2017), and in forging inroads into new places with new products as a means of expanding markets and profitability (e.g. Johnson, 2013b). Likewise, insurance logics pervade government and societal thinking about risk and responsibility, and exert control over what is and is not considered possible. Law and Mol (2001), however, describe how object fluidity can be quite free flowing, responsive to place and circumstance, and potentially 'far removed from the control-drive of the modern subject' (de Laet and Mol, 2000: 251). This is adaptation where agency is more distributed and less constituted through hegemonic power. The agency demonstrated by householders, subsistence farmers and the places where they live and work (e.g. Booth and Harwood, 2016; Johnson, 2013b) appears to constitute these kinds of adaptive, potentially ahegemonic insurance realities.

In concert with the themes of governmentality, materiality and spatiality reviewed in this paper, the idea of mobility - geographies of mobility - could contribute new and novel dimensions to critical insurance studies. Leveraging Merriman's (2012) observation that human geography is too focused on reified notions of space and time, there are worthwhile opportunities for considering 'other registers, apprehensions, engagements and movements that appear to be important for understanding the unfolding of many events' (Merriman, 2012: 24). What might be revealed about the practices of insuring, for example, in light of multiple registers of motion and emotion (Sheller and Urry, 2006) or shifting atmospheres of everyday life and governance (Adey, 2015)? Focusing on the diverse forces that enable, inhibit or stop movement or mutability, how might insurance be rethought in regard to Cresswell's (2010) 
proposition for a politics of mobility, or this proposition progressed in light of insights gained from insurance research? In understanding the same type of insurance as constituted through multiple realities and distributed agencies, then what possibilities, beyond the hegemonic, might be gleaned through the mutable, mobile qualities of insurance?

Glimmers of possibilities are evident in existing insurance research, though require further explication. For example, for property insurance, Booth and Kendal (2020) observe that the process of financialisation co-produces rather than mitigates underinsurance. Changes brought about by housing financialisation contribute to a rise in renting which in turn is associated with underinsurance. They conclude 'that in negating or resisting insurance marketisation, [renting] households garner everyday financial and material adaptative capacity by underinsuring' (Booth and Kendal, 2020: 728). In other words, household resources and expectations are reconfigured to enable an alternative reality that appears to run parallel to a reality in which insurance is a normative signifier and 'common sense'. Research that considers 'other registers, apprehensions, engagements and movements' (Merriman, 2012: 24) appears likely to reveal new dimensions of property insurance within decisions made by these households not to insure. This includes how renter insurance realities may change and adapt as renter-specific products and marketing strategies travel in different ways in different places and become entangled within the affect materialities of everyday life.

\section{Conclusion}

In this review of critical insurance studies, I have highlighted three ofttimes intersecting and overlapping bodies of work- those pertaining to governmentality, materiality and spatiality. Critical reflection upon the latter, draws attention to other ways of thinking through place and space and possibilities arising from paying more attention to mobility in insurance research. Specifically, considering how fluid and fire space (Law and Mol, 2001; Law, 2002; Law and Singleton, 2005) bring new and novel insights to the question, what is insurance?

As discussed, insurance - even the same type of insurance - can change form and function as it adapts and morphs within the context of everyday life and global financial markets. This gradual fluid change can be understood as part of the continuity and success of insurance. Insurance can also be composed of dynamic and juxtaposed flickering, fiery presences and absences, the otherness of which also constitute the continuity of insurance. The multiple realities that are insurance - that are the same type of insurance - appear to enable its existence and given this location within the hegemony, the insurance sector is a powerful 
arbiter of this flow and flickering. This arbitration occurs through intersecting processes such as governmentalisation and financialisation.

Yet, this power is far from absolute and critical insurance studies reveals contradictions, schisms and tensions within the multiplicity of insurance. Insurance - the very nature of insurance - is open to contestation, and as such this prevalent and pervasive part of everyday life invites re-understanding and re-configuration. Critical geographers can play a much more significant role in this regard, in re-imagining more socio-spatially equitable forms of insurance and insurantial futures. This appears particularly important given the unknown implications of the rapid integration of insurtech - big data and analytics - into insurance products and thus, everyday life.

These insights can also contribute to critical financial studies more generally. Thinking through financial tools, mechanisms and processes in terms of fluid and/or fire space, can shed new light on the multiplicity, mobility and contestability of these. This, in turn, may continue to illustrate and challenge hegemonic orthodoxies and reveal alternative modes of knowing and praxis within finance and economics, and thus progress more equitable finance futures.

\section{References}

Adey P (2015) Air's affinities: Geopolitics, chemical affect and the force of the elemental. Dialogues in Human Geography 5(1): 54-75.

Agger B (1998) Critical Social Theories: An Introduction. Boulder, CO: Westview Press. Anderson B and Wylie J (2009) On geography and materiality. Environment and Planning A: Economy and Space 41: 318-335.

ACCC (2019) Northern Australia insurance inquiry second update report. Canberra, Australia: Australian Competition and Consumer Commission.

Baker T (1996) On the genealogy of moral hazard. Texas Law Review 75(2): 237-292. Baldwin A (2017) Resilience and race, or climate change and the uninsurable migrant: Towards an anthroporacial reading of 'race'. Resilience 5(2): 129-143.

Bennett J (2009) Vibrant Matter: A Political Ecology of Things. Durham, UK; Duke University Press. 
Blomley N (2009) Critical human geography. In: Gregory D, Johnston R, Pratt G, Watts MJ and Whatmore S (eds.) The Dictionary of Human Geography. Chichester, UK: WileyBlackwell, pp. 123-124.

Booth K (2020) Insurance, and the prospects of insurability. In: Knox-Hayes J and Wójcik D (eds.) The Routledge Handbook of Financial Geography. New York: Routledge, pp. 400-420. Booth K (2021) Firescapes of disruption: An absence of insurance in landscapes of fire. Environment and Planning E: Nature and Space 4(2): 525-544.

Booth K and Harwood A (2016) Insurance as catastrophe: A geography of house and contents insurance in a bushfire prone area. Geoforum 69: 44-52.

Booth K and Kendal D (2020) Underinsurance as adaptation: Household agency in places of marketization and financialization. Environment and Planning A: Economy and Space 52(4): 728-746.

Booth K and Tranter B (2018) When disaster strikes: Under-insurance in Australian households. Urban Studies 55(14): 3135-3150.

Borch C (2020) Introduction: What is critical finance studies? In: Borch C and Wosnitzer R eds.) The Routledge Handbook of Critical Finance Studies. New York: Routledge, pp. 1-25.

Castree N (2000) Professionalization, activism, and the university: Whither 'critical geography'? Environment and Planning A: Economy and Space 32(6): 955-970.

Christophers B (2019) The allusive market: insurance of flood risk in neoliberal Britain. Economy and Society 48(1): 1-29.

Christophers B, Bigger P and Johnson L (2020) Stretching scales? Risk and sociality in climate finance. Environment and Planning A: Economy and Space 52(1): 88-110.

Clark GL (2003) Pension security in the global economy: Markets and national institutions in the 21st century. Environment and Planning A 35(8): 1339-1356.

Collier S (2014) Neoliberalism and natural disaster: Insurance as political technology of catastrophe. Journal of Cultural Economy 7(3): 273-290.

Cresswell T (2010) Towards a politics of mobility. Environment and Planning D: Society and Space 28: 17-31.

de Laet M and Mol A (2000) The Zimbabwe bush pump: Mechanics of a fluid technology. Social Studies of Science 30: 225-263. 
Elliot R (2017) Who pays for the next wave? The American welfare state and responsibility for flood risk. Politics \& Society 45(3): 415-440.

Elliott R (2019) "Scarier than another storm": Values at risk in the mapping and insuring of US floodplains. The British Journal of Sociology 70(3): 1067-1090.

Ericson R and Doyle A (2004) Catastrophic risk, insurance and terrorism. Economy and Society 33(2): 135-173.

Ewald F (1991) Insurance and risk. In: Burchell G, Gordon C and Miller P (eds.) The Foucault Effect: Studies in Governmentality. Hertfordshire, UK: Harvester Wheatsheaf, pp. 197-210.

Fay B (1987) Critical Social Science: Liberation and its Limits. Ithaca, NY: Cornell University Press.

French S and Kneale J (2009) Excessive financialisation: Insuring lifestyles, enlivening subjects, and everyday spaces of biosocial excess. Environment and Planning D: Society and Space 27: 1030-1053.

French S and Kneale J (2012) Speculating on careless lives: Annuitising the biofinancial subject. Journal of Cultural Economy 5(4): 391-406.

French S and Kneale J (2015) Insuring biofinance: Alcohol, risk and the limits of life. Economic Sociology 17(1): 16-24.

French S, Leyshon A and Wainwright T (2011) Financializing space, spacing financialization. Progress in Human Geography 35(6): 798-819.

Grove K (2012) Preempting the next disaster: Catastrophe insurance and the financialization of disaster management. Security Dialogue 43(2): 139-155.

Hall S (2010) Geographies of money and finance I: Cultural economy, politics and place. Progress in Human Geography 35(2): 234-245.

Harker C and Montgomerie J (2021) Household finance. In: Knox-Hayes J and Wójcik D (eds.) The Routledge Handbook of Financial Geography. New York: Routledge, pp. 308-327. Jeanningros H and McFall L (2020) The value of sharing: Branding and behaviour in a life and health insurance company. Big Data and Society. Epub ahead of print 10 September 2020. DOI: $10.1177 / 2053951720950350$ 
Johnson L (2013a) Catastrophe bonds and financial risk: Securing capital and rule through contingency. Geoforum 45: 30-40.

Johnson L (2013b) Index insurance and the articulation of risk-bearing subjects. Environment and Planning A: Economy and Space 45: 2663-2681.

Johnson L (2015) Catastrophic fixes: Cyclical devaluation and accumulation through climate change impacts. Environment and Planning A: Economy and Society 47: 2503-2521.

Jong L and M'charek A (2018) The high-profile case as 'fire object': Following the Marianne Vaatstra murder case through the media. Crime Media Culture 14(3): 347-363.

Kiohos A and Paspati M (2021) Alternative to insurance risk transfer: Creating a catastrophe bond for Romanian earthquakes. Bulletin of Applied Economics, Risk Market Journals 8(1): $1-17$.

Knight D, Noble F, Vurdubakis T and Willmott H (2001) Chasing shadows: Control, virtuality and the production of trust. Organisational Studies 22(2): 311-336.

Langley P (2006) The making of investor subjects in Anglo-American pensions. Environment and Planning D: Society and Space 24: 919-934.

Latour B (1990) Drawing things together. In: Lynch M and Woolgar S (eds.) Representation in Scientific Practice. Cambridge, MA: MIT Press, pp. 19-68.

Law J (2002) Objects and spaces. Theory, Culture \& Society 19(5/6): 91-105.

Law J and Singleton V (2005) Object lessons. Organisation 12(3): 331-355.

Law J and Mol A (2001) Situating technoscience: An inquiry into spatialities. Environment and Planning D: Society and Space 19: 609-621.

Lehtonen T (2014) Picturing how life insurance matters. Journal of Cultural Economy 7(3): 308-333.

Lehtonen T (2017) Domesticating insurance, financializing family lives: The case of private health insurance for children in Finland. Cultural Studies 31(5): 685-711.

Lehtonen T and Van Hoyweghen I (2014) Editorial: Insurance and the economization of uncertainty. Journal of Cultural Economy 7(4): 532-540.

Lo A (2013) The likelihood of having flood insurance increases with social expectations. Area 45(1): 70-76. 
Lobo-Guerrero L (2010) Insurance, climate change, and the creation of geographies of uncertainty in the Indian Ocean Region. Journal of the Indian Ocean Region 6(2): 239-251. Lobo-Guerrero (2011) Insuring Security: Biopolitics, Security and Risk. Oxon, UK: Routledge.

Lobo-Guerrero L (2013) Uberrima Fides, Foucault and the security of uncertainty. International Journal of the Semiotics of Law 26: 23-37.

Lobo-Guerrero L (2014) The capitalisation of 'excess life' through life insurance. Global Society 28(3): 300-316.

Lucas C and Booth K (2020) Privatizing climate adaptation: How insurance weakens solidaristic and collective disaster recovery. WIREs Climate Change. Epub ahead of print 11 August 2020. DOI: $10.1002 /$ wcc.676

McAneney J, McAneney D, Musulin R, Walker G and Crompton R (2016) Governmentsponsored natural disaster insurance pools: a view from down-under. International Journal of Disaster Risk Reduction 15: 1-9.

McFall L (2011) A 'good, average man': calculation and the limits of statistics in enrolling insurance customers. The Sociological Review 59(4): 661-684.

McFall L (2015) Devising Consumption: Cultural Economies of Insurance, Credit and Spending. Abingdon, UK: Routledge.

McFall L (2019) Personalizing solidarity? The role of self-tracking in health insurance pricing. Economy and Society 48(1): 52-76.

McFall L, Meyers G and Van Hoyweghen I (2020) Editorial: The personalisation of insurance: Data, behaviour and innovation. Big Data and Society. Epub ahead of print 26 November 2020. DOI: 10.1177/2053951720973707

McFall L and Moor L (2018) Who, or what, is insurtech personalizing?: Persons, prices and the historical classifications of risk. Distinktion: Journal of Social Theory 19(2): 193-213. Merriman P (2012) Human geography without time-space. Transactions of the Institute of British Geographers 37: 13-27.

Meyers G and Van Hoyweghen I (2018) Enacting actuarial fairness in insurance: From fair discrimination to behaviour-based fairness. Science as Culture 27(4): 413-438. 
Meyers G and Van Hoyweghen I (2020) 'Happy failures': Experimentation with behaviourbased personalisation in car insurance. Big Data and Society. Epub ahead of print 1 April 2020. DOI: $10.1177 / 2053951720914650$

Mouffe C (2005) On the Political. Abingdon, NY: Routledge.

Müller B, Johnson L and Kreuer D (2017) Maladaptive outcomes of climate insurance in agriculture. Global Environmental Change 46: 23-33.

Murdoch J (1998) The spaces of actor-network theory. Geoforum 29(4): 357-374.

Nance E (2015) Exploring the impacts of flood insurance reform on vulnerable communities. International Journal of Disaster Risk Reduction 13: 20-36.

O’Malley P and Roberts A (2013) Governmental conditions for the economization of uncertainty: Fire insurance, regulation and insurance actuarialism. Journal of Cultural Economy 7(3): 253-272.

Ossandón J (2014) Reassembling and cutting the social with health insurance. Journal of Cultural Economy 7(3): 291-307.

Pike A and Pollard J (2010) Economic geographies of financialization. Economic Geography 86(1): 29-51.

Pittham F and De Witte K (2021) Puzzles of insurance demand and its biases: A survey on the role of behavioural biases and financial literacy on insurance demand. Journal of Behavioural and Experimental Finance 30: 100471.

Sheller M and Urry J (2006) The new mobilities paradigm. Environment and Planning A: Economy and Space 38(2): 207-226.

Taylor ZJ (2020) The real estate risk fix: Residential insurance-linked securitization in the Florida metropolis. Environment and Planning A: Economy and Society 52(6): 1131-1149. Tanninen M (2020) Contested technology: Social scientific perspectives of behaviour-based insurance. Big Data and Society. Epub ahead of print 7 September 2020. DOI: $0.1177 / 2053951720942536$

Tranter B and Booth K (2019) Geographies of trust: Socio-spatial variegations of trust in insurance. Geoforum 107: 199-206.

Van Hoyweghen I (2010) Taming the wild life of genes by law? Genes reconfiguring solidarity in private insurance. New Genetics and Society 29(4): 431-455. 
Zelizer VAR (2017) Morals and Markets: The Development of Life Insurance in the United

States. New York, NY: Columbia University Press.

\footnotetext{
' Insurance research in the social sciences, including human geography, is still very much in a growth phase, coming off a relatively small base. Borch (2020: 1) observes that 'finance and financial markets are such complex structures that they often resemble quasi-autonomous phenomena that... appear to neutralize any external pressure'. In addition, there appears an,

almost dialectical relationship between finance and critique [that] may ... serve as

a cautious reminder for critical studies of finance: critiques may be voiced for good reasons, but may also bring about changes, the negative effects of which might by worse than (or only marginally preferable to) the starting point (Borch, 2020: 2).
}

As Hall (2010) points out, these types of perception appear to have informed the slow uptake of economics and finance research more generally in the social sciences, and it is, perhaps, that this concern that wellintentioned research may be co-opted that has led to interest in insurance research being even slower and more reluctant; a concern that 'all-powerful' insurers will do what they do best and make profit out of misfortune including any unfortunate critique that is levelled against them or their products.

ii These characteristics are contested inside and outside of critical human geography as lacking explicit emancipatory direction (e.g. Agger, 1998) and, through its recent uptake across human geography, a dilution of its radical intent (e.g. Castree, 2000). 